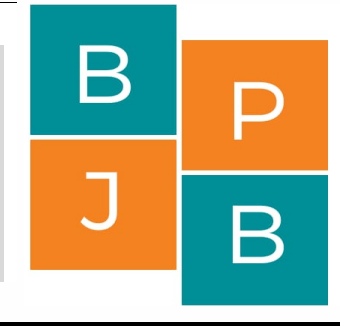

\title{
Improving metacognitive skills using problem based learning (pbl) at natural science of primary school in deli serdang, indonesia
}

\author{
Anggi Tias Pratama* \\ Biology Education, Faculty of Teacher Training and Education, Universitas Muslim Nusantara
}

*Corresponding author: gietyas@gmail.com

\section{A R T I C L E I N F O}

Article history:

Received 28 September 2018

Revised 24 October 2018

Accepted 29 October 2018

Keywords:

Metacognitive, problem based

learning (PBL), science.

\begin{abstract}
A B S T R A C T
Metacognitive skills are one of the skills needed in a 21st century lesson in science learning. Empowerment of thinking and metacognitive skills needs to be done so that learners become independent learners. Metacognitive skills are influenced by learning strategies. This PBL strategy in learning is expected to help students to improve students' metacognitive abilities in science learning. This study aims to determine the improvement of metacognitive skills of students who are taught with $P B L$ strategies. The results showed that PBL strategies can improve students' metacognitive skills on different abilities. The students' metacognitive improvement on PBL strategy is $73.93 \%$ and conventional is $59.51 \%$. PBL strategy can be used in science learning to improved metacognitive skill in Deli Serdang.
\end{abstract}

(C) 2018 Universitas Negeri Jakarta. This is an open access article under the CC-BY license

(https://creativecommons.org/licenses/by/4.0)

\section{INTRODUCTION}

The Education was to realize society that is competitive and innovative, experiences various challenges, especially the quality of education. To improve the Indonesian's society that has competitiveness and innovation, educational products must be adequate both in terms of quantity and quality. Human Development Report Index(2013) reported Indonesian's ranking education $121^{\text {st }}$ from number 187 countries.

The determinative of educational quality in order to compete nationally and internationally in the $21^{\text {st }}$ century, require skills that used to compete including: 1) thinking skills that includes critical thinking, problem solving, creativity, and metacognitive; 2) communication and collaboration skills that is able to communicate and collaborate effectively with the various parties; 3 ) creativity and innovation skills that is able to develop its creativity to generate innovative breakthroughs; 4) information and communications technology literacy that is able to utilize information and 
communication technologies to improve the performance and activities of daily life; 5) contextual learning skills that is capable of undergoing self-contextual learning activities as part of personal development; and 6) information and media literacy skills that is able to understand and use a variety of communication media to convey ideas, implement collaborative activities, and interaction with various parties (Greenstein, 2012).

Metacognition is a term introduced by Flavell (1976) and is interpreted as a knowledge of cognitive process. Metacognition is closely related to cognitive learning outcome. Wellman (1985) stated that metacognition is a form of cognition or second level or more thinking process that includes cognitive activity control.

The science learning pattern at Deli Serdang is still oriented towards cognitive learning outcomes and has not attempted to empower students' cognitive skills. Based on the observations of researchers on teaching science subjects, less than $25 \%$ of teachers attempted to empower metacognitive abilities in providing learning through the application of learning strategies. Empowerment of thinking and metacognition skills needs to be done so that students become independent learners learning strategies (Corebima, 2009; Paidi, 2008; Warouw, 2009; Danial, 2010; and Sepe, 2010, Muhlisin, 2012, Djamahar, et al., 2018).

Learning strategies that are considered appropriate to apply are strategies based on constructivist approaches such as Problem Based Learning (PBL) strategies. PBL is based on learning not only the process of memorizing concepts or facts but the process of interaction between individuals and their environment. PBL can also develop skills needed in the knowledge age (Duch et al., 2001; Tan, 2003) because it can develop higher-order thinking skills such as critical thinking, problem solving, finding and using learning resources, independent learning, developing work skills cooperative, and lifelong learning (Steck, et al., 2012). PBL can be applied in schools because PBL is based on problems, involves thinking activities to solve problems, and correlates with students' cognitive functions (Izzaty, 2006). PBL increases learning motivation (Keziah, 2010), has the potential to empower metacognitive skills (Ackay, 2009; Corebima, 2010; Danial, 2010), and increase student retention power (Muhiddin, 2012).

Based on PBL's excess rationality and absence data on improving elementary metacognitive abilities, it is necessary to do research on "Improving Metacognitive Skills by Using Problem Based Learning (PBL) Learning Strategies at Natural Science Learning at Primary School in Deli Serdang"

\section{METHOD}

The population used in this research was primary school students in Deli Serdang, Indonesia, with a number of 22 schools. The sample in this research was 232 students who were randomly selected from each school. This research used was quasi-experimental research design with $2 \times 2$ factorial version non equivalent group design.Quasi experimental Nonequivalent Pretest-Posttest Control Group Design procedure is further shown in Table 1.

Table 1. Quasi experimental Nonequivalent Pretest-Posttest Control Group Design.

\begin{tabular}{lcc}
\hline \multirow{2}{*}{ Grade Point } & \multicolumn{2}{c}{ Learning Srategies (S) } \\
\cline { 2 - 3 } & PBL(S1) & Conventional (S2) \\
\hline High (K1) & S1K1 & S2K1 \\
Low (K2) & S1K2 & S2K2 \\
\hline
\end{tabular}

Students' metacognitive skills were measured using the Metacognitive Skills Inventory (MSI) adapted from MAI (Schraw \& Dennison, 1994) and SEMLI-S (Thomas, et al., 2008). This inventory consists of 34 statement items which are divided into skills in planning, monitoring, evaluation, and revising. Inventories are validated before use.

Research data were analyzed using descriptive statistics to show descriptions or profiles of metacognition skills. Descriptive statistical values include mean, standard deviation, highest average, lowest average, and percentage change in pretest with posttest. In addition, the score data for the 
dependent variable is displayed in graphical.Inferential statistics of two-way covariate analysis (ANACOVA) with a significance level of 5\% are used to test the hypothesis of difference. Data were analyzed using SPSS 20.0 for Windows.

\section{RESULT AND DISCUSSION}

Table 2.Average value and percentage of change in pretest-posttest value metacognitive skills measured with rubrics on each learning strategy according to academic ability.

\begin{tabular}{|c|c|c|c|c|c|c|}
\hline \multirow{2}{*}{ No } & \multirow{2}{*}{ Learning Strategies } & \multirow{2}{*}{ Academic ability } & \multicolumn{2}{|c|}{ Average } & \multirow{2}{*}{$\begin{array}{c}\text { Changes } \\
(\%)\end{array}$} & \multirow{2}{*}{ Explanation } \\
\hline & & & Pretest & Posttest & & \\
\hline \multirow{3}{*}{1} & \multirow{3}{*}{ PBL } & High Academic & 18.45 & 52.16 & 64.62 & Increased \\
\hline & & Low Academic & 9.32 & 43.62 & 78.63 & Increased \\
\hline & & Total & 13.14 & 50.39 & 73.93 & Increased \\
\hline \multirow{3}{*}{2} & \multirow{3}{*}{ Conventional } & High Academic & 25.99 & 52.62 & 50.61 & Increased \\
\hline & & Low Academic & 8.90 & 33.53 & 73.46 & Increased \\
\hline & & Total & 17.44 & 43.07 & 59.51 & Increased \\
\hline \multirow{2}{*}{\multicolumn{2}{|c|}{ Total }} & High Academic & 26.44 & 56.47 & 52.91 & Increased \\
\hline & & Low Academic & 13.61 & 43.77 & 68.19 & Increased \\
\hline
\end{tabular}

Based on Table 2 it can be seen that the metacognitive skills of students taught with PBL and conventional learning have increased with varying percentages both between learning strategies, different academic abilities, and a combination of learning strategies and academic abilities. Average data on the value of metacognitive skills measured using the essay test can be visualized as in Figure 1 .

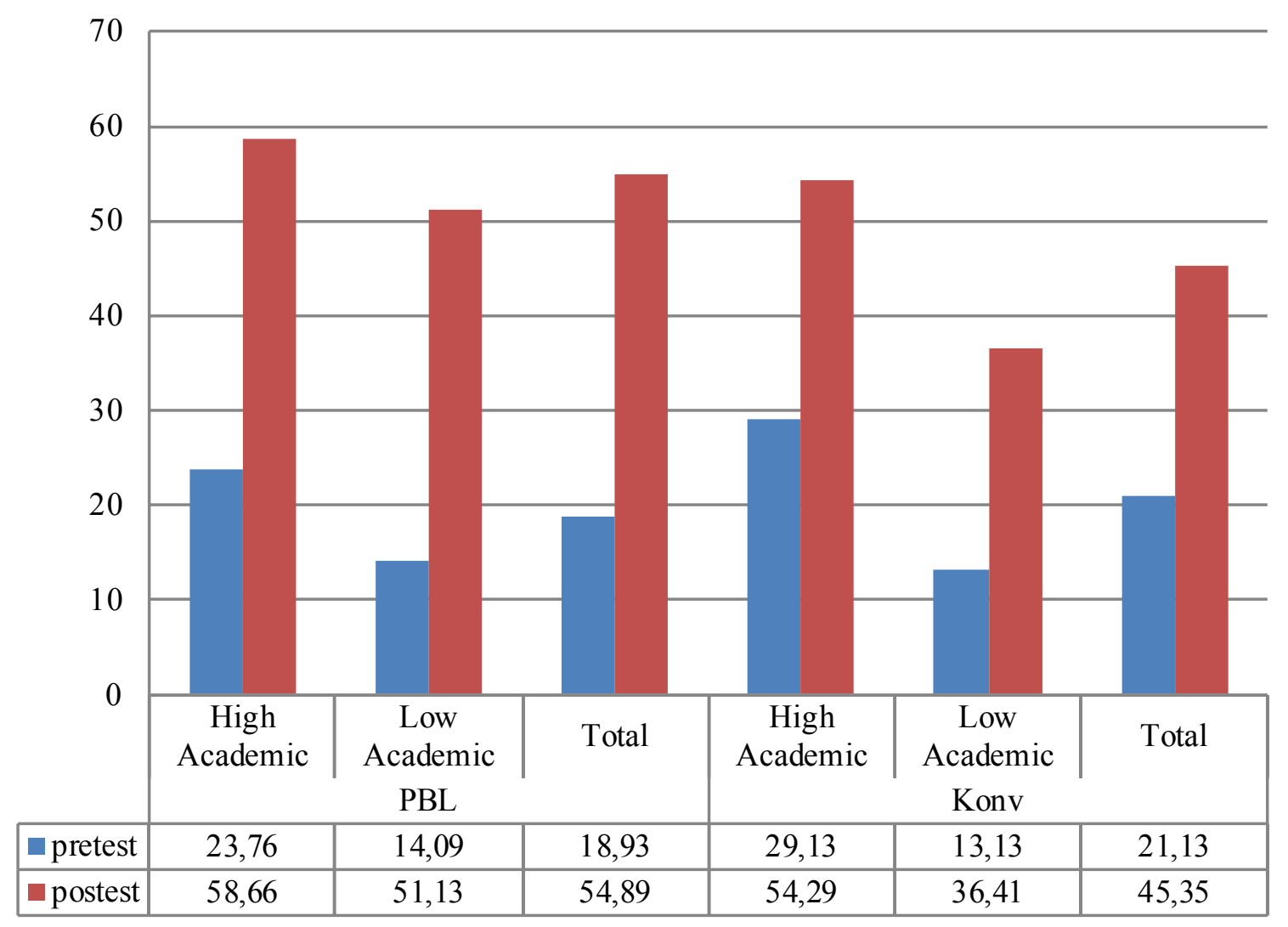

Figure 1. Average Pretest-Posttest Value of Cognitive Learning Outcomes in Each Learning Strategy According to Academic Ability. 
Students' metacognitive skills are measured using rubrics and through the Metacognitive Skills Inventory (MSI). Summary Hypothesis testing with children of students' metacognitive skills as measured by the rubric seen in table 2 .

Table 3. Summary of anova test results student metacognitive skills measured with rubrics.

\begin{tabular}{lrrrrr}
\hline \multicolumn{1}{c}{ Source } & $\begin{array}{c}\text { Type III Sum of } \\
\text { Squares }\end{array}$ & df & Mean Square & F & Sig. \\
\hline Corrected Model & $19644.057^{\mathrm{a}}$ & 8 & 2455.507 & 15.997 & .000 \\
Intercept & 59223.890 & 1 & 59223.890 & 385.837 & .000 \\
Xmet & 4859.427 & 1 & 4859.427 & 31.659 & .000 \\
Strategy & 8690.798 & 3 & 2896.933 & 18.873 & .000 \\
Academic ability & 1085.884 & 1 & 1085.884 & 7.074 & .009 \\
Strategy * & 320.163 & 3 & 106.721 & .695 & .557 \\
Academic ability & 20414.765 & 133 & 153.494 & & \\
Error & 371756.311 & 142 & & & \\
Total & 40058.822 & 141 & & & \\
Corrected Total & & & & & \\
\hline
\end{tabular}

Based on the source of the learning strategy and academic ability, p-level was smaller than alpha $0.05(\mathrm{p}<0.05)$ with sig. 0.000 and 0.009 . This means that Ho who states that "There is no influence of learning strategies and academic abilities on students 'metacognitive skills" is not accepted and the research hypothesis stating "There is an influence of learning strategies and academic abilities on students' metacognitive skills" is accepted. Based on the interaction sources of learning strategies with academic abilities obtained $p$-level is greater than alpha $0.05(\mathrm{p}>0.05)$ with sig. 0.557. This means that Ho stating that "There is no effect of interaction of learning strategies with academic abilities on students 'metacognitive skills" is accepted and the research hypothesis which states "There is an influence of the interaction of learning strategies with academic abilities on students' metacognitive skills" is not accepted. It can be concluded that there is a significant influence of learning strategies and academic abilities on students 'metacognitive skills, but there is no influence of the interaction of learning strategies with academic abilities on students' metacognitive skills.

The results showed that there was an influence of learning strategies on students' metacognitive skills measured using rubrics. The results of this study are in line with the results of Sungur \& Tekkaya (2006), Paidi (2008), Suratno (2009), Danial (2010), Corebima (2011a) who discovered the influence of learning strategies on metacognitive skills.

The learning strategies affect students' metacognitive skills as measured by rubrics, where students who are taught with PBL strategies get the highest corrected scores, while those between conventional and not taught are high. The lowest score is seen in conventional learning strategies. This shows that both PBL learning strategies have potential in empowering students' metacognitive skills. And research findings indicate that PBL strategies complement each other and increasingly maximize the potential of both in empowering metacognitive skills.

Increased metacognitive skills of students who are taught with PBL strategies, namely in this strategy, through PBL stages, students are faced with a real-world problem that is ill-structured. With such problems, students will try to make the problem clear and well-structured. Students will formulate several possible hypotheses and their solutions based on information from various reading sources. The activities of learners that occur during PBL implementation seem clearly to involve metacognition. Of course the activities of students in PBL's steps are the benchmarks if in PBL metacognition occurs (Downing et al., 2009). Correspondingly, Ackay (2009) and Corebima (2010) report that PBL has the potential to empower metacognitive skills. PBL enhances metacognitive selfregulation (Sungur \& Tekkaya, 2006) and causes the process of thinking and learning. According to 
Pratama (2016) emotional intelligence contributes to cognitive learning outcomes. Downing, et al. (2009) found that PBL accelerates metacognition development at the student level.

Through the PBL stages, it is possible for students to participate, and face the problem of solving small groups during the learning process (Yuan, 2008). In this strategy, the problem is the first step in gathering and integrating new knowledge (Muhson, 2009) and facilitates learners to learn through solving real and authentic world problems and integrating interdisciplinary knowledge (Keziah, 2010). Ambunan (2018) and (Ristanto, 2011) states that the living environment influences students' knowledge. The same thing was also found by Tanjung (2018) contextual learning strategies are better than conventional ones. One of the main objectives of the PBL learning stage is to direct students' self-development to be skilled in recognizing the need for learning, setting their own learning goals, defining relevant questions for study, accessing relevant information, testing in-depth understanding of what has been learned (Savin-Baden \& Major, 2004).

\section{CONCLUTION}

The students' metacognitive improvement on PBL strategy is $73.93 \%$ and conventional is $59.51 \%$. Based on the results of this research, it is suggested that teachers can be used PBL strategy in science learning to improved metacognitive skill in Deli Serdang.

\section{REFERENCE}

Ackay, B. (2009). Problem-based learning in science education. Journal of Turkish Science Education, 6(1), 26 -36.

Corebima, A. D. (2009). Jadikan Peserta Didik Pebelajar Mandiri. Makalah. Disampaikan pada Seminar di UNM pada tanggal 19 Desember 2009.

Corebima, A. D. (2010). BerdayakanKeterampilanBerpikirSelamaPembelajaranSains Demi Masa Depan Kita. Makalah Disampaikan pada Seminar Nasional Sains di Unesa pada Tanggal 16 Januari 2010.

Corebima, A. D., \& Bahri, A. (2011). Reading, Questioning, and Answering (RQA): A New Learning Strategy to Enhance Student Metacognitive Skill and Concept Gaining. Paper presented at International Symposium at Nanyang Technology University, Singapura, 2011.

Danial, M. (2010.)Pengaruh Strategi Pembelajaran PBLdan GI terhadap Metakognisi dan Penguasaan Konsep Kimia Dasar Siswa Jurusan Biologi FMIPA UNM. Disertasi tidak diterbitkan. Malang: PPS UM.

Downing, K., Kwong, T., Chan, S. W., Lam, T. F., \& Downing,W. K. (2009). PBL and Development of Metacognition. High Education Journal, 57, 609 - 621. doi: 10.1007/s10734-008-9165-x.

Duch, B. J,.Groh, S.E., \& Debora.E. A. (2011). The Power of Problem Based Learning: A Practical "How To" for Teaching Undergraduate Courses in Any Discipline. Sterling: Stylus Publishing.

Djamahar, R., Ristanto, R.H., Sartono, N., Ichsan, I.Z., \& Muhlisin, A. (2018). Cirsa: designing instructional kits to empower $21^{\text {st }}$ century skill. Educational Process: International Journal, 7(3), 200-208. http://dx.doi.org/10.22521/edupij.2018.73.4

Flavell, J. H. (1976). Metacognitive Aspect of Problem Solving. In L. B. Resnick (Ed.), The Nature of Intelligence (pp.231-236). Hillsdale, NJ: Erlbaum Association.

Greenstein, L. (2012). Assesing 21 st Century Skill, A Guide To Evaluating Mastery and Authentic Learning. USA: Corwin A Sage Company.

Izzaty, R. E. (2006). Problem based learning dalam pembelajaran di perguruan tinggi. Paradigma, $1(1), 77-83$. 
Keziah, A. A. (2010). A comparative study of pbl and lecture-based learning in secondary school students' motivation to learn science. International Journal of Science and Technology Education Research, 1(6), 126 - 131.

Muhiddin. (2012). Pengaruh integrasi problem-based learning dengan pembelajaran kooperatif jigsaw dan kemampuan akademik terhadap metakognisi, berpikir kritis, pemahaman konsep, dan retensi mahasiswa pada perkuliahan biologi dasar. Disertation Unpublish. Malang: PPS Universitas Negeri Malang.

Muhson, A. (2009). Peningkatan minat belajar dan pemahaman mahasiswa melalui penerapan problem-based learning. Jurnal Kependidikan, 39(2), 171 - 182.

Paidi. (2008). Pengembangan perangkat pembelajaran biologi yang mengimplementasikan pbl dan strategi metakognisi, serta efektifitasnya terhadap kemampuan metakognitif, pemecahan masalah, dan penguasaan konsep biologi siswa sma di sleman yogyakarta. Disertation unpublish. Malang: PPS Universitas Negeri Malang.

Ristanto, R. H. (2011). Pembelajaran biologi berbasis inkuiri terbimbing dengan multimedia dan lingkungan rill terhadap prestasi belajar. Jurnal Educatio, 6(1), 53-68.

Savin-Baden, M. \& Major, C.H. (2004). Foundations of Problem-based Learning. Buckingham: Open University Press.

Schraw. G., \& Dennison, R. S. (1994). Assessing metacognitive awareness. Contemporary Educational Psychology, 19(4), 460-475.

Sepe, F. Y. (2010). Pembelajaran metakognitif pada strategi pembelajaran kooperatif tai dan pengaruhnya terhadap keterampilan metakognitif, kemampuan berpikir kritis dan hasil belajar kognitif sains biologi pada siswa smp swasta di kota kupang. Thesis unpublish. Malang: PPS Universitas Negeri Malang.

Steck, T.R., DiBiase, W., Wang, C., \& Boukhtiarov, A. (2012). The use of open-ended pbl scenarios in an interdisciplinary biotechnology class: evaluation of a pbl course across three years. Journal of Microbiology \& Biology Education, 13(1), 2-10.

Sungur, S., \& Tekkaya, C. (2006). Effect of Problem Based Learning and Traditional Instruction on Self-Regulated Learning. The Journal of Educational Research. Vol. 99 (5): 307-317.

Suratno. (2009). Pengaruh Strategi Kooperatif Jigsaw dan Resiprocal Teacning terhadap Keterampilan Metakognisi dan Hasil Belajar Biologi Siswa SMA Berkemampuan Atas dan Bawah di Jember. Disertation unpublish. Malang: PPS Universitas Negeri Malang.

Tanjung, I. F. (2018). Perbedaan hasil belajar strategi pembelajaran kontekstual dan strategi pembelajaran discovery mis istiqomah al-ulya tahun ajaran 2017- 2018. Jurnal Raudhah, 6(1), $1-23$.

Tan, O. S. (2003). Problem Based Learning Innovation. Using Problem to Power Learning in the 21st Century. Singapure: Cengage Learning Asia Pte. Ltd.

Thomas, G., Anderson, D. \& Nashon, S. (2008). Development of An Instrument Designed to Investigate Elements of Science Students' Metacognition, Self-Efficacy and Learning Processes: The SEMLI-S. International Journal of Science Education, 30(13), 1701-1724.

Warouw, Z. W. M. (2009). Pengaruh pembelajaran metakognitif dengan strategi cooperative script, dan reciprocal teaching pada kemampuan akademik berbeda terhadap kemampuan dan keterampilan metakognitif, berpikirkritis, hasil belajar biologi siswa, serta retensinya di smp negeri manado, (Disertation unpublish), PPS UniversitasNegeri Malang, Malang. 
Wellman, H. (1985). The origins of metacognition. In D.L.Forrest-Pressley, G.E.MacKinnon, and T. G. Waller (Eds.), Metacognition, Cognition, and Human Performance, Volume 1- Theoretical Perspectives, chapter 1. Academic Press, Inc.

Yuan, H., Kunaviktikul, W., Klunklin, A., \& Williams, B. A. (2008). Promoting critical thinking skills through problem-based learning. Journal of Social Science and Humanities, 2(2), 85-100. 